\title{
Acceleration of Islamic Bank Financing in Indonesian Agriculture Sector
}

\author{
Faizul Mubarok
}

Faculty of Islamic Economics and Business, UIN Syarif Hidayatullah Jakarta, Indonesia

Corresponding email: fayzmubarok@uinjkt.ac.id

doi) http://dx.doi.org/10.22515/shirkah.v6i2.341

\begin{tabular}{|c|c|}
\hline ARTICLE INFO & ABSTRACT \\
\hline $\begin{array}{l}\text { Keywords: } \\
\text { Agriculture Sector; Exchange } \\
\text { Rates; Inflation; Interest Rates; } \\
\text { Islamic Banking Financing } \\
\text { Article history: } \\
\text { Received: } 27 \text { September } 2020 \\
\text { Revised: } 09 \text { December } 2020 \\
\text { Accepted: } 12 \text { December } 2020 \\
\text { Available online: } 13 \text { July } 2021 \\
\text { To cite in APA style: } \\
\text { Mubarok, F. (2021). } \\
\text { Acceleration of Islamic Bank } \\
\text { Financing in Indonesian } \\
\text { Agriculture Sector. Shirkah: } \\
\text { Journal of Economics and } \\
\text { Business, 6(2), 185-204. }\end{array}$ & $\begin{array}{l}\text { Economic instability is a challenge for Islamic banks in } \\
\text { channeling financing to various sectors including } \\
\text { agriculture. This study aims to shed some light on the } \\
\text { influence of economic indicators and the financing response } \\
\text { to agriculture sector using monthly data from } 2006 \text { to } 2020 \text {, } \\
\text { including data from agriculture sector financing, interest } \\
\text { rates, inflation, exchange rates, Islamic stock index, and } \\
\text { composite stock index. This study employed Vector Error } \\
\text { Correction Model (VECM) method. The results revealed that } \\
\text { only interest rates and inflation affected Islamic bank } \\
\text { financing in the short and long term period. Islamic bank } \\
\text { financing in the agriculture sector reached the fastest } \\
\text { stability when responding to exchange rate shocks. The } \\
\text { results further showed that interest rates mostly influenced } \\
\text { the level of diversity in Islamic bank financing in the } \\
\text { agriculture sector. The results suggest that stakeholders need } \\
\text { to play a crucial role in stabilizing economic turmoil to } \\
\text { accelerate Islamic bank financing particularly in agriculture } \\
\text { sector. }\end{array}$ \\
\hline
\end{tabular}

This work is licensed under a Creative Commons Attribution-NonCommercial 4.0 International License.

\section{Introduction}

In the recent years, Indonesia's agricultural sector has a significant contribution to the Gross Domestic Product (GDP). Based on the data, agriculture is the second largest sector after the manufacture in terms of GDP contribution. However, due to the highrisk industry category, the sector's financing is relatively lower than in other industries. Table 1 shows the financing of each sector where the agricultural sector is in the 6th position of the economic sector. 
Faizul Mubarok: Acceleration of Islamic Bank Financing in Indonesian Agriculture Sector

Table 1. Islamic Banking Financing to Various Sectors (in Billion Rupiah)

\begin{tabular}{lllllll}
\hline Economic Sector & $\mathbf{2 0 1 5}$ & $\mathbf{2 0 1 6}$ & $\mathbf{2 0 1 7}$ & $\mathbf{2 0 1 8}$ & $\mathbf{2 0 1 9}$ & $\mathbf{2 0 2 0}$ \\
\hline Agricultural & 9,148 & 9,936 & 11,882 & 12,807 & 15,024 & 17,171 \\
Mining and Quarrying & 6,145 & 6,604 & 6,864 & 5,852 & 5,086 & 5,583 \\
Procesing Industry & 17,982 & 19,745 & 21,463 & 22,662 & 26,488 & 28,723 \\
Electricity, Gas, and Water & 6,427 & 8,117 & 11,044 & 16,584 & 14,055 & 11,581 \\
Construction & 11,193 & 14,435 & 22,198 & 23,341 & 31,167 & 37,986 \\
Wholesale and Retail Trade & 25,993 & 30,319 & 32,839 & 32,646 & 36,752 & 39,936 \\
Provision of accommodation & 2,101 & 3,043 & 3,613 & 4,197 & 4,988 & 4,902 \\
Transportation, Warehousing & 11,072 & 10,921 & 10,087 & 10,214 & 9,925 & 11,659 \\
Financial intermediaries & 19,184 & 18,948 & 19,583 & 17,351 & 19,388 & 14,608 \\
Real Estate & 9,365 & 12,797 & 12,326 & 12,368 & 13,404 & 12,187 \\
Services & 10,616 & 11,770 & 14,231 & 15,920 & 20,831 & 16,488 \\
\hline
\end{tabular}

Several indicators consider agriculture as a vital sector. First, its natural resources are considerable potential (Speirs, McGlade, \& Slade, 2015). Second, the substantial and significant agricultural sector contribute to workforce absorption (Nolte \& Ostermeier, 2017). Third, agriculture sector plays a role in the rural growth. The agricultural sector also has the potential to reduce poverty (Christiaensen, 2017). However, the agricultural sector is still facing complicated problems, especially capital assistance, to start an agricultural business no matter how small it is (Graeub et al., 2016). National banking, theoretically, has excellent potential as a supporter of agricultural financing due to its legal position as an intermediary financial institution (Arun \& Kamath, 2015). Hence. the role of financial institutions is vital in helping to provide capital for people who want to do business (Ozili, 2018).

To manage agricultural resources efficiently, Efficient management of agricultural resources requires a production method in the form of technology for the use of agricultural inputs and tools and machinery so that it requires capital in an institutional forum (Antle et al., 2017; Fielke et al., 2020; Taylor, \& Jakku, 2020; Wolfert et al., 2017). The availability and accessibility of capital sources by economic actors is essential both as working capital (purchasing production inputs) and for investment capital (landing acquisition and purchase) (Gardner et al., 2019; Krishna et al., 2017). Several studies show that the distribution of technology application is linear with the distribution of capital availability. Lack of capital has always been a classic problem for most agricultural business actors, including farmers (Shankland \& Gonçalves, 2016). Meanwhile, there are still many potential funds in the banking sector that have not been widely used for the agricultural sector (Rothenberg et al., 2016).

Sharia patterns can be alternative financing for the agricultural sector, and especially the most important thing is to avoid usury (Wahyudi \& Sani, 2014). In other words, no additional funds from returns are taken by banks outside of the agreement 
and principle of funds (Salman \& Nawaz, 2018). Besides, the sharia pattern tends not to take sides with one of the financings of both banks and customers but instead provides mutual benefit, namely by sharing profits and losses (Aysan \& Disli, 2019).

Amid the continuous acceleration of financing for the agricultural sector, Islamic banking must face the global economy (Louhichi \& Boujelbene, 2016). The role of banking as an intermediary institution in a country and profitable institutions in the financial industry must read and understand the market situation (Gatfaoui, 2017). The factors that influence financing include economic conditions, government policies, bank capital position, and third-party funds stability (Godil et al., 2020; Kudrin \& Gurvich, 2015). However, other factors also determine the distribution of bank financing, namely changes in banking behavior and the monetary authorities' behavior and the financial sector, influencing economic activity and bringing about monetary policy (Aysan, Disli, \& Ozturk, 2018; Kavya \& Shijin, 2020).

Inflation and interest rate movements fluctuate along with the observation. Also, conditions for the rupiah exchange rate, the Islamic stock index, and the composite stock index experienced fluctuating movements (Mahapatra \& Bhaduri, 2019). The instability of global economic conditions will affect the portion of Islamic banks' financing in the agricultural sector (Rizvi et al., 2019). Economic conditions will impact business sustainability in the agricultural sector, considering that this sector has a significant role in the Indonesian economy (Mueller \& Mueller, 2016). Because of that, it is necessary to anticipate the impact of these global economic shocks.

Thus, this study aims to analyze the influence of economic indicators and the financing response to the agricultural sector. Using Vector Error Correction Model (VECM), the results of this study have potential contributions. First, this study contributes to providing knowledge for academics and the broader community regarding Islamic banks' role in developing the agricultural sector and its impact in channeling financing to the agricultural sector. Second, recommendation material and evaluation material can be used by interested actors in making decisions policies to develop financing to the agricultural sector through Islamic banking.

\section{Hypothesis Development}

Exchange Rate

The exchange rate is one of the essential variables of a country that adopts an open economic system (Sinyakov \& Yudaeva, 2016). The exchange rate will experience changes in value and is relatively unstable due to supply and demand changes from time to time (Yin \& Ma, 2018). Strengthening or weakening of the exchange rate will significantly affect the distribution of financing provided by Islamic bank to the public (Nahar \& Sarker, 2016).

Galadima and Aminu (2019) examined the transmission of shocks from the money 
supply, inflation, exchange rates, and real GDP to natural gas consumption using the Structural Vector Autoregression (SVAR) model. The results showed that natural gas consumption responded significantly to shocks to the money supply and real GDP in the short and long term, while the response to inflation shocks was only significant in the short term.

Lin, Shi, and Ye (2018) discuss credit in determining exchange rate volatility's trading effect. Exchange rate volatility hurts companies. The financial sector has a more negative exposure of trading volume to exchange rate volatility. Also, the trading effect of exchange rate volatility varies widely and can be positive or negative, depending on the degree of credit constraint.

H1: The exchange rate affects Islamic bank financing

\section{Inflation}

Inflation is an increase in the price of goods in general and continuously, thus reflecting the people's weakening purchasing power, which is followed by a decline in the value of a country's real currency (El Alaoui, Jusoh, Yussof, \& Hanifa, 2019; Hossain, 2016; Naifar, 2016). Thus, if there is an increase in inflation, investors will increase the nominal return rate, aiming to protect the real return rate (Aluko \& Ajayi, 2018).

Bahloul, Mroua, and Naifar (2017) studied the impact of conventional stock market returns and macroeconomic volatility on Islamic stock market returns using Markov Switching Autoregression (MS-VAR). The empirical results show that the Islamic stock index's development is influenced by returns on the conventional stock index and the money supply when volatility is low and high. However, other macroeconomic variables cannot explain the Islamic stock index dynamics, especially during high volatility periods.

Kandil (2014) used annual data with a sample of developing countries to analyze shocks from monetary policy. The effect of monetary shocks increases as the elasticity of demand increases. In line with the monetary policy stabilization function, output growth declined in response to monetary fluctuations between countries.

H2: Inflation affects Islamic bank financing

\section{Interest Rate}

Monetary policy in the short run will affect output in the short run and will adjust to it in the long run (Cieslak \& Schrimpf, 2019). Monetary policy with a price approach uses an interest rate indicator to its operational target (Werner, 2016). The BI Rate serves as a signal to respond to monetary policy and operational banking targets. The rise and fall of interest rates will indirectly affect the distribution of Islamic banking financing.

Caporale et al. (2020) examined the lending channel of monetary transmission banks in Malaysia during 1994-2015 using the Threshold Vector Autoregression 
(TVAR) model. This study takes into account the relationship between bank loans and monetary policy in different economic conditions. The results show that Islamic credit is less responsive than conventional credit when responding to interest rate shocks.

El Alaoui et al. (2019) analyze the relationship between money, interest rates, inflation, exchange rates, industrial production index, and equity index in Malaysia. The relationship between monetary policy variables and macroeconomic variables has non-homogeneous developments and trends across time scales. Several strong correlations were found in Malaysia's monetary policy using the quantity of money, interest rates, and exchange rates that drive some interactions.

Hamza and Saadaoui (2018) discuss the monetary transmission mechanism through Islamic bank debt financing channels. Its purpose is to test whether this channel is working effectively and whether Islamic banks' reaction to interest rates depends on their characteristics. This study uses a sample of 50 Islamic banks with the dynamic panel method from 2005-2014. The study results confirm a debt financing channel from the monetary policy because variations in interest rates affect Islamic bank financing. Growth, capitalization, asset liquidity, and the size of the profit-sharing investment accounts (PSIA) are the main determinants of Islamic bank debt assets.

H3: Interest rate affects Islamic bank financing

\section{Capital Market}

The capital market plays a facilitating role between capital owners and companies that register their companies' stock exchange (Khmel \& Zhao, 2016). The capital market consists of a primary market and a secondary market (Naqvi et al., 2018). The number of firms and the intensity of transactions on the secondary market directly influence capital market developments (Alam et al., 2017).

Apergis et al. (2019) examine the transmission dynamics between the real interest rate and the gold price in the G7 (Canada, France, Germany, Italy, Japan, the United Kingdom, and the United States). The methodology uses the Bayesian MarkovSwitching Vector Error-Correction (MS-VECM) model, which covers 1975-2016. The results showed a positive relationship between gold prices and real interest rates. The price of gold can hedge against movements in real interest rates, especially during times of recession.

$\mathrm{Wu}$ and Zeng (2019) investigates the impact of liquidity constraints on the Chinese stock market by analyzing hedgers, speculators, and arbitrage trading behavior. The method used is the Vector Error Correction Model (VECM) for the CSI 300 index and the CSI 300 index futures. The results show that liquidity in both indices performs well in explaining massive levels of base persistence. The direction of the divergence depends on the future price relationship.

Ellington (2018) examines the relationship between financial liquidity and 
macroeconomic dynamics using VAR in UK stocks. The results show that liquidity conditions on the stock market were illiquid; there were significant differences in economic shocks and a substantial increase during the 2008 recession.

H4: Capital market affects Islamic bank financing

\section{Method}

\section{Research Design and Sample Selection}

This study analyzes the effect of the economy in the short and long term on agricultural sector financing. The response to agricultural sector financing is facing economic shocks and each variable's contribution in explaining the diversity of agricultural sector financing. The research data come from the Financial Services Authority, Bank Indonesia, and the Central Statistics Agency. The research sample consisted of Islamic Commercial Banks and Sharia Business Units.

\section{Instrumentation and Data Collection}

This study uses monthly secondary data from June 2006 to June 2020 from Indonesian Islamic banking's statistical reports. The data collected is in the form of data on Islamic banking financing in the agricultural sector (AGR), the exchange rate (EXC), inflation (INF), interest rate (RATE), Islamic stock index (JII), and the composite stock index (IHSG).

\section{Variable Measurement}

This study uses Vector Error Correction Model (VECM) approach to answer the research problem formulation. The vector autoregression analysis (VAR) analysis is a data description, forecasting, structural inference, and policy analysis. As for the first VAR test steps, the data stationarity test used the Augmented Dickey-Fuller (ADF) test and the Phillips-Perron (PP) test. Second, the optimal lag test used the Akaike Information Criterion (AIC). Third, the VAR stability test to test the stability of the model was administered. Fourth, the cointegration test uses the Johansen Cointegration test. Fifth, the VAR model estimation was further conducted. Sixth, the Impulse Response Function (IRF) test was implemented. IRF is useful for tracking each variable's current and future responses due to a particular variable's change or shock. Seventh, Forecast Error Variance Decomposition (FEVD) was used to predict the percentage contribution of each variable's variance to changes in a particular variable. The formula below was used:

$$
\Delta y_{t}=m_{0 x}+m_{1 x} t+\prod_{x} y_{t-1}+\sum_{i=1}^{k-1} C_{i x} \Delta y_{t-1}+e_{t}
$$

Where: $\Delta y_{t}$ is a vector containing the variables analyzed in the study (AGR), $m_{0 x}$ is the intercept vector, $m_{1 x}$ is the regression coefficient vector, $\mathrm{t}$ is the time trend, $\prod_{x} y_{t-1}$ is the long-term cointegration equation with the $\mathrm{y}$ in variable level, $\mathrm{C}_{i x}$ is the regression 
coefficient matrix, $\mathrm{k}-1$ is the VECM order of VAR, dan $e_{t}$ is the error term.

\section{Results}

\section{Stationarity Test}

Table 2 shows the results of the data stationarity test in this study. The stationarity test reveals that AGR, EXC, RATE, JII, and IHSG variables are not stationary (the ADF value is more than $5 \%$ ), while the INF variable is stationary (the ADF value is less than $5 \%$ ). The test results using PP show that AGR, EXC, and IHSG are not stationary at the level (more than 5\%), while INF, RATE, and JII are stationary (less than 5\%). As a consequence of the absence of stationarity at that level, this study tested the difference. The difference level test result shows that all data are stationary using either the ADF test or the PP test.

Table 2. Data Stationarity Test Results

\begin{tabular}{lllll}
\hline \multirow{2}{*}{ Variable } & \multicolumn{2}{l}{ Augmented Dickey-Fuller Test } & \multicolumn{2}{l}{ Phillips-Perron Test } \\
\cline { 2 - 5 } & Level & Difference & Level & Difference \\
\hline AGR & 0.9210 & 0.0000 & 0.8826 & 0.0000 \\
EXC & 0.6380 & 0.0000 & 0.6416 & 0.0000 \\
INF & 0.0014 & 0.0000 & 0.0011 & 0.0000 \\
RATE & 0.0297 & 0.0000 & 0.0302 & 0.0000 \\
JII & 0.1024 & 0.0000 & 0.0973 & 0.0000 \\
IHSG & 0.1816 & 0.0000 & 0.1672 & 0.0000 \\
\hline
\end{tabular}

\section{Optimal Lag Testing}

This test is to observe the behavior and relationships of each variable in the system. If the lag is too short, the regression residual will not display the white noise process, so the model cannot accurately estimate the actual error. However, if the lag is too long, the degree of freedom will be more significant, so that it is not efficient in explaining. Therefore, VAR estimation is very sensitive to the lag length used. Also, testing the optimal lag length is very useful for eliminating autocorrelation problems in the VAR system so that by using the optimal lag, there is no autocorrelation problem.

Determination of the amount of lag to be used in the VAR model can be determined based on the Akaike Information Criterion (AIC), Schwarz Criterion (SC), or Hannan-Quinn (HQ) criteria. Table 3 is the result of determining the optimal lag. In this study, the optimum lag test used the smallest SIC value. Therefore, the results show that lag 1 is the optimal lag in this study.

Table 3. Optimal Lag Test Results

\begin{tabular}{lllllll}
\hline Lag & Lolo & LR & FPE & AIC & SC & HQ \\
\hline 0 & 1241.464 & NA & $8.71 \mathrm{e}-15$ & -15.34737 & -15.23254 & -15.30075 \\
1 & 2408.802 & 2233.169 & $6.86 \mathrm{e}-21^{*}$ & $-29.40126^{*}$ & $-28.59742^{*}$ & $-29.07487^{*}$ \\
2 & 2438.310 & $54.25197^{*}$ & $7.45 \mathrm{e}-21$ & -29.32063 & -27.82777 & -28.71447 \\
\hline
\end{tabular}




\begin{tabular}{lllllll}
\hline Lag & Lolo & LR & FPE & AIC & SC & HQ \\
\hline 3 & 2456.043 & 31.27969 & $9.39 \mathrm{e}-21$ & -29.09370 & -26.91184 & -28.20778 \\
4 & 2485.112 & 49.11100 & $1.03 \mathrm{e}-20$ & -29.00761 & -26.13673 & -27.84192 \\
5 & 2505.697 & 33.24271 & $1.27 \mathrm{e}-20$ & -28.81612 & -25.25623 & -27.37066 \\
6 & 2529.235 & 36.25744 & $1.51 \mathrm{e}-20$ & -28.66131 & -24.41242 & -26.93609 \\
7 & 2552.313 & 33.82806 & $1.83 \mathrm{e}-20$ & -28.50078 & -23.56288 & -26.49579 \\
8 & 2568.042 & 21.88354 & $2.45 \mathrm{e}-20$ & -28.24897 & -22.62205 & -25.96421 \\
\hline
\end{tabular}

*indicates lag order selected by the criterion

LR: sequential modified LR test statistic (each test at $5 \%$ level)

FPE: Final prediction error

AIC: Akaike information criterion

SC: Schwarz information criterion

HQ: Hannan-Quinn information criterion

\section{VAR Model Stability Testing Results}

The VAR model stability test uses a method by calculating the roots of the polynomial function. If all the polynomial function roots are in the unit circle or the absolute value is less than 1, then the VAR model is considered stable. VAR stability needs to be tested first before conducting further analysis because if the VAR estimation results and error correction models are unstable, the Impulse Response Function and Variance Decomposition will be invalid. The results of the stability test with lag 1 indicate that the lag is stable (See table 4).

Table 4. VAR Model Stability Test Results

\begin{tabular}{lc}
\hline Root & Modulus \\
\hline 0.994876 & 0.994876 \\
0.938218 & 0.938218 \\
$0.875101-0.101472 \mathrm{i}$ & 0.880964 \\
$0.875101+0.101472 \mathrm{i}$ & 0.880964 \\
0.867175 & 0.867175 \\
0.760139 & 0.760139 \\
\hline
\end{tabular}

No root lies outside the unit circle.

VAR satisfies the stability condition.

\section{Cointegration Test Results}

The existence of non-stationary variables causes the possibility of a long-term relationship between the variables in the system. The cointegration test aims to determine the relationship between these variables, especially in the long term. If there is cointegration in the model variables, there is a long-term relationship between the variables. The method for testing the existence of this cointegration is the Johansen cointegration method. The cointegration test results indicate that there is cointegration in the variables studied (see table 5). 
Table 5. Cointegration Test Results

\begin{tabular}{lllll}
\hline $\begin{array}{l}\text { Hypothesized } \\
\text { No. of CE(s) }\end{array}$ & Eigenvalue & $\begin{array}{l}\text { Trace } \\
\text { Statistic }\end{array}$ & $\begin{array}{l}\mathbf{0 . 0 5} \\
\text { Critical Value }\end{array}$ & Prob. $^{* *}$ \\
\hline None & 0.282797 & 156.9653 & 117.7082 & 0.0000 \\
At most $1{ }^{*}$ & 0.231919 & 102.4523 & 88.80380 & 0.0037 \\
At most 2 & 0.165083 & 59.17933 & 63.87610 & 0.1166 \\
At most 3 & 0.119332 & 29.58998 & 42.91525 & 0.5266 \\
At most 4 & 0.037722 & 8.749733 & 25.87211 & 0.9671 \\
At most 5 & 0.014789 & 2.443581 & 12.51798 & 0.9350 \\
\hline
\end{tabular}

Trace test indicates two cointegrating eqn(s) at the 0.05 level

*denotes rejection of the hypothesis at the 0.05 level

**MacKinnon-Haug-Michelis (1999) p-values

\section{Estimation Vector Error Correction Model (VECM)}

VECM is a restricted form of VAR because of a non-stationary but cointegrated data form. The VECM specification restricts long-term relationships so that they converge in their cointegration but still allow short-term relationships. The VECM model is selected based on the goodness of fit criteria. Table 6 is the VECM estimation result of the Islamic banking sector financing model in the agricultural sector in the short and long term. In the short term, the interest rate (RATE) significantly affects Islamic banking financing in the agricultural sector, while others do not affect it. Meanwhile, only inflation (INF) in the long term has a significant effect on Islamic banking financing in the agricultural sector, while others do not affect it.

Table 6. VECM Estimation Results

\begin{tabular}{lll}
\hline \multirow{2}{*}{ Variable } & Coefficient & [t-statistic] \\
\cline { 2 - 3 } & Short Term & {$[-1.16647]$} \\
CointEq1 & -0.001790 & {$[-0.37874]$} \\
D(EXC(-1)) & -0.037846 & {$[1.06999]$} \\
D(INF(-1)) & 0.383896 & {$[2.10285]^{*}$} \\
D(RATE(-1)) & 1.475443 & {$[0.43698]$} \\
D(JII(-1)) & 0.092156 & {$[-0.92533]$} \\
D(IHSG(-1)) & -0.212189 & {$[5.74918]$} \\
C & 0.024365 & \\
\hline Long Term & & {$[-1.47027]$} \\
\hline EXC & & {$[6.34746]^{*}$} \\
INF & -9.071197 & {$[-1.74316]$} \\
RATE & 143.5320 & {$[-0.05044]$} \\
JII & -72.98224 & {$[-0.26364]$} \\
IHSG & -0.460063 & - \\
C & -2.578356 & \\
\hline
\end{tabular}

*Significant at $5 \%$

\section{Impulse Response Function}

Impulse Response Function (IRF) analysis explains shocks' impact from one variable on 
other variables in the short and long term. Agricultural sector financing responded positively to exchange rate shocks (EXC) of 0.002623 percent in the second period (see figure 1). This period is the highest response throughout the observation. The third period, the financing response decreased to 0.001605 percent, then rose again to 0.001677 percent in the fourth period. Exchange rate volatility continued to move with nominal value and began to stabilize in the ninth period until the end of the observation.

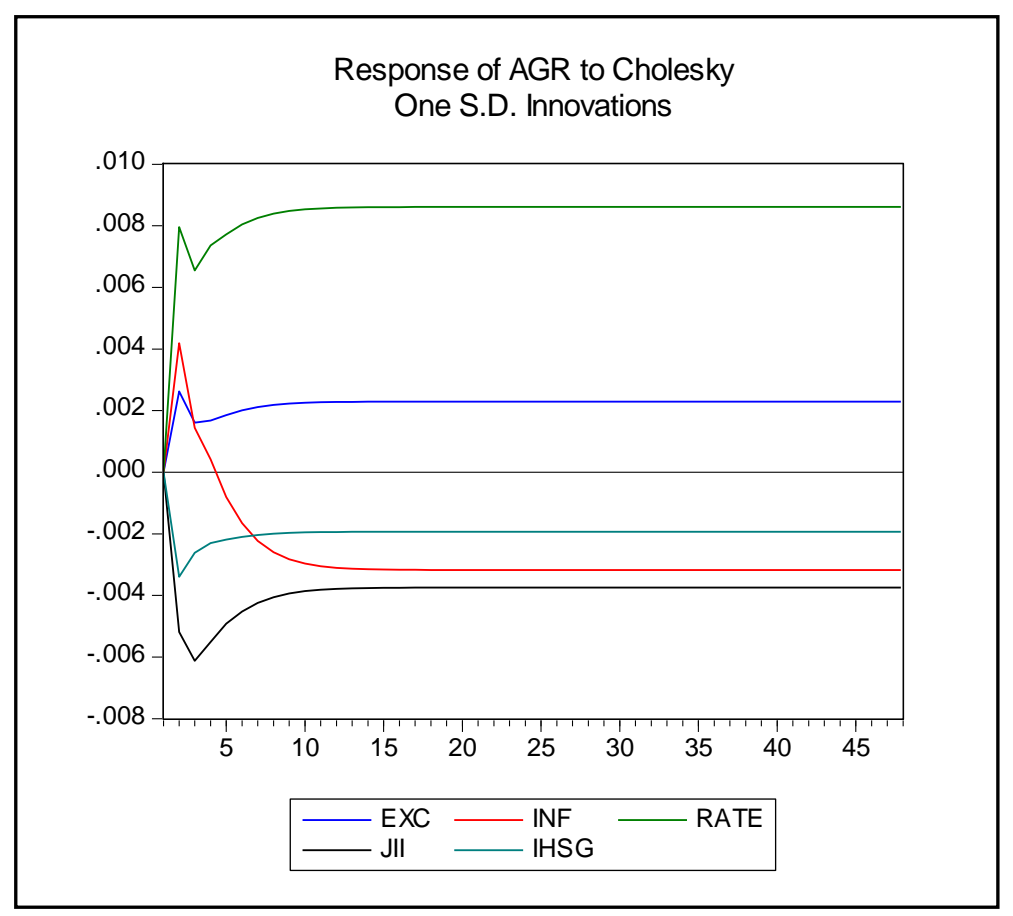

Figure 1. The Response of Agricultural Sector Financing to Economic Shocks

Agricultural sector financing responded positively to inflation shocks (INF) of 0.004192 percent in the second period. Then it decreased to 0.001445 percent in the third period. It fell again to -0.000805 percent in the fifth period and continued to be negative until the end of the observation. Inflation shocks continued to move and began to stabilize when entering the eleventh period.

Agricultural sector financing responded positively to the interest rate shock (RATE) of 0.007961 percent in the second period. Then the third period fell to 0.007366 percent. The response to interest rate shocks starts to stabilize when entering the tenth period of 0.008533 percent until the end of the observation.

Agricultural sector financing responded negatively to the Jakarta Islamic Index (JII) shock of -0.005184 percent in the second period. It fell to -0.006128 percent in the third period, which was the lowest point in response to the JII shock. The next period experienced an increase and began to stabilize when entering the eleventh period until the end of the observation of -0.003814 percent. 
Agricultural sector financing responded negatively to the Jakarta Composite Index (IHSG) shock of -0.003396 percent in the second period. In the third period, it increased to -0.002614 percent. The next period has increased back to -0.002302 percent. In the eleventh period, until the end of the observation, it began to stabilize with a value of -0.001946 percent.

\section{Forecast Error Variance Decomposition}

Forecast Error Variance Decomposition (FEVD) analysis aims to analyze each variable's fluctuation due to a shock occurrence. Long-term analysis using the VECM model through variant decomposition simulation aims to analyze various shocks' effects. The Variance Decomposition results in the agricultural sector financing model (AGR) show that AGR innovation causes the variance forecasting interval.

Figure 2 is a simulation of variance forecasting. The first period of economic variable shocks was influenced by sharia financing shocks by 100 percent, while other variables did not affect. The contribution of shocks to economic variables began to be felt in the second period, although the percentage was tiny. Changes in economic conditions take time to affect other aspects. Interest rate shocks gave the most considerable contribution compared to other economic variables in this period by 1.51 percent and continued to increase until the end of the observation.

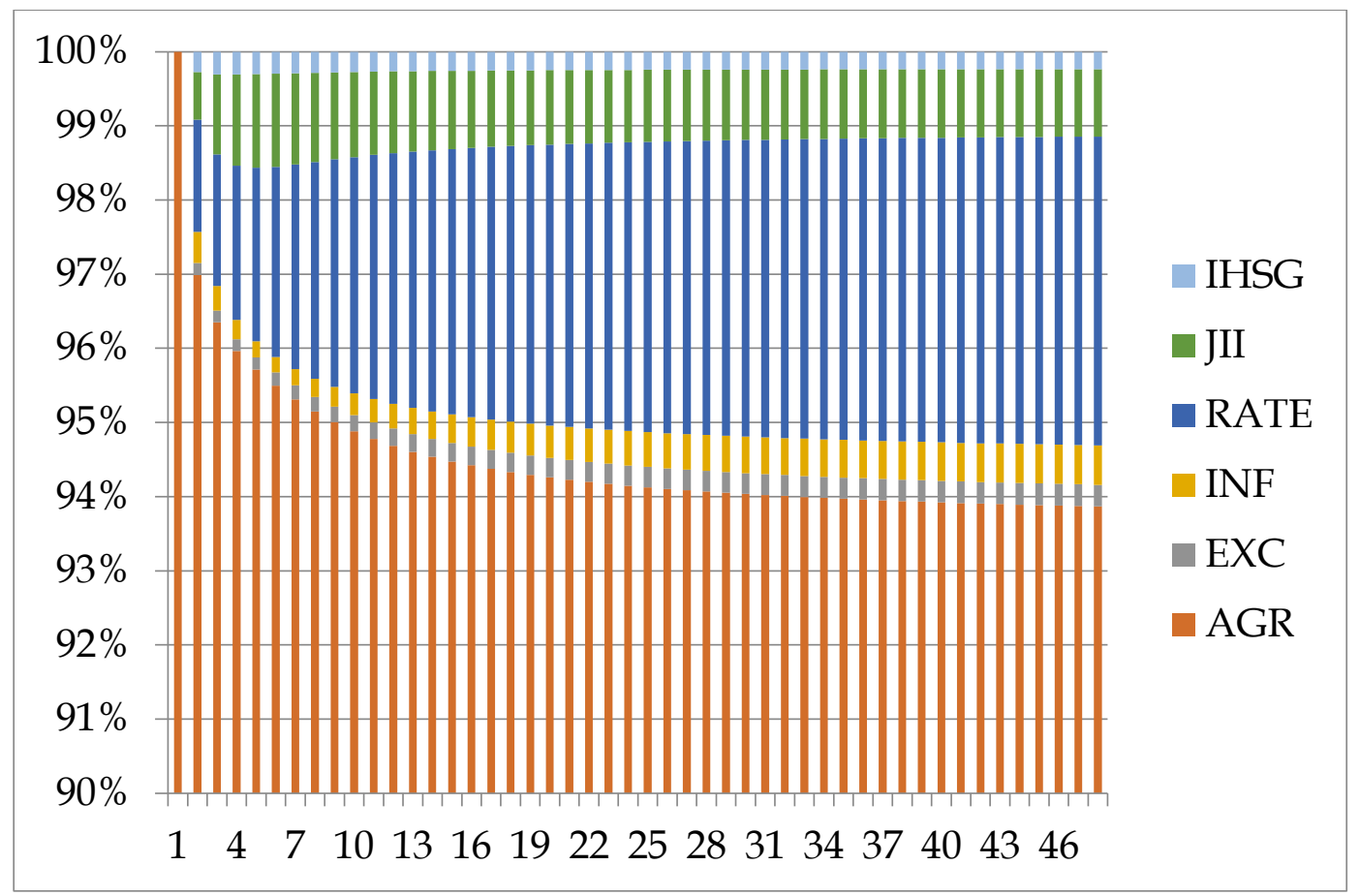

Figure 2. Results of Forecast Error Variance Decomposition

The Islamic stock index (JII) was ranked second in this period with a contribution of 0.64 percent, followed by the influence of inflation of 0.42 percent, then the composite stock index of 0.275 percent, and finally the exchange rate of 0.164 percent. The AGR shock effect decreases with time; meanwhile, other economic variables provide an 
increasing contribution, although it is relatively small. The FEVD results indicate that Islamic financing innovations, such as exchange rates, inflation, interest rates, Islamic stock index (JII), and composite stock index (IHSG), have a smaller effect than innovations in financing itself.

\section{Discussion}

\section{Short-term and Long-term Effects}

Estimates, in the long run, show that only inflation (INF) has a significant effect on distributed financing (AGR). Meanwhile, in the short term, only the interest rate (RATE) affects the financing that is distributed (AGR). An increase in INF in the long term of one percent will increase financing by 143.5 percent. This condition illustrates that an increase in inflation will undoubtedly accompany economic growth. The more a country's economy grows, the better the investment climate will be (Nwakoby \& Bernard, 2016).

The strengthening value of the currency indicates that economic conditions are much better. However, in this study, currency movements did not affect. These two factors are the main factors as indicators of economic growth. Likewise, with the increase in the benchmark interest rate, this increase was responded positively and significantly in the short term, but not significant in the long term. There are still debtors who are customers of Islamic banking, who refer to the interest rate compared to the profit-sharing rate (Aysan \& Disli, 2019). Besides, if there is an increase in interest rates, deposit and credit interest rates will increase (Hamza \& Saadaoui, 2018). This increase results in higher costs incurred by the customer to pay interest on the loan. Therefore, customers choose Islamic banking as alternative financing.

An increase in the Jakarta Islamic Index (IHSG) and the Jakarta Islamic Index (JII) by one percent will cause a decrease in financing by 2.57 percent and 0.46 percent. However, these results are not significant. Changes in capital market conditions did not significantly affect the distribution of Islamic banking financing. These results indicate that investors engaged in the agricultural sector do not rely on capital market conditions (Hossain, Muhammad, Jibril, \& Kaitibie, 2019).

\section{Islamic Banking Financing Response to Exchange Rate Shocks}

The relationship between exchange rates and bank financing has no direct effect; however, through the transmission of interest rates in dampening high fluctuations in the exchange rate. Islamic banking does not only compete with similar banks but also with conventional banking. This competition is in the profit-sharing rate movement in line with changes in interest rates (Šeho, Bacha, \& Smolo, 2020).

Islamic banking financing in the agricultural sector is more dominated by the Murabaha contract, a fixed margin buying and selling scheme (Hossain et al., 2019). 
The practice of buying and selling through the Murabaha scheme has set a margin at the contract time. Murabaha schemes such as usury where the bank and the customer determine the return rate at the beginning of the contract, although the transaction has not occurred (Sofhian, 2015). Besides, when viewed from the traders' point of view, the profits to be made depending on market conditions (Ayedh, Shaharuddin, \& Kamaruddin, 2019).

The exchange rate condition, which always fluctuates, often affects the commodities being traded (Sugiharti, Esquivias, \& Setyorani, 2020). When there is depreciation, imported products will be more expensive. Debtors who will buy agricultural equipment at a specific price will feel a loss when the exchange rate strengthens. Therefore, customers will think more rationally about looking for cheaper financing sources when the exchange rate depreciates.

\section{Islamic Banking Financing Response to Inflation Shock}

Besides influencing banking performance, inflation policy also affects capital market activities (Lawal et al., 2018). The right policy will undoubtedly have a positive impact. The establishment of an expansionary inflation policy will push stock prices positively, thereby affecting increased bank financing (Cieslak \& Schrimpf, 2019; Ellington, 2018). The amount of financing provided by banks is, of course, influenced by several other economic variables.

If it is linked to theory, the effect of inflation harms the distribution of bank financing. If inflation increases, people tend to reduce investment. This condition will impact the decline in banking assets in real terms because the funds collected have decreased, affecting banking operations' ability to channel financing (Chockalingam, Dabadghao, \& Soetekouw, 2018). When viewed from a debtor's point of view, inflation is very beneficial because, at the time of debt repayment, the value of money is lower than when borrowed (Chadwick, 2018). Conversely, those who lend money will experience losses because the value of the money returned will be lower than at the time of borrowing (Nayak, Pai, \& Pai, 2016).

Public concerns regarding inflation have been responded positively by the continued growth in financing (Siami-Namini \& Hudson, 2019). This condition shows that the returns obtained from the banking revenue sharing system with customers and the profits obtained by debtors from banking financing sources are much higher than the inflation that occurs (Hossain, 2016).

\section{Islamic Banking Financing Response to Interest Rate Shocks}

The resulting inflationary pressure requires the central bank to raise the benchmark interest rate to reduce it (Coibion et al., 2020). Financial operations carried out by the central bank by increasing the benchmark interest rate by several basis points aim to 
reduce inflation (El Alaoui et al., 2019). Debtors responded negatively to the increase in bank interest rates in the short term because they were worried about the company's financial liquidity (Ayedh et al., 2019). Of course, this is related to the costs incurred and the systemic impact that is likely to arise.

The central bank's benchmark interest rate will encourage banks to increase their loan and deposit interest rates, aiming to stimulate customers to increase their savings funds (Werner, 2016). When viewed from the demand side, an increase in loan interest rates negatively correlates with the loan amount because borrowers' interest costs are higher (Fecke, Feil, \& Musshoff, 2016).

Islamic banking is a substitute for conventional banking. When there is an increase in interest rates, it will impact the movement of customers who will apply for credit from conventional banking to Islamic banking because the costs incurred by debtors will be greater than before the interest rate hike (Kabir, Worthington, \& Gupta, 2015; Rashid, Hassan, \& Shah, 2020). This condition is called displaced commercial risk, where when interest rates are in an increasing phase, debtors will switch to looking for substitute sources of financing from Islamic banking and vice versa (Bitar, Pukthuanthong, \& Walker, 2019).

\section{Islamic Banking Financing Response to Stock Index Shocks}

Sharia stocks tend to have a stronger resistance to economic shocks when domestic and global economic conditions are still unstable (Bahloul et al., 2017). The Islamic stock market does not recognize banking stocks because it cannot include stocks whose business type has an interest system (Alam et al., 2017). Meanwhile, the portion of banking shares is relatively high in the Indonesian capital market. When there are economic shocks, most of them are affected by the banking sector (Hossain, 2016).

However, the negative response to Islamic banking financing is due to alleged observations due to the large number of debtors playing on the stock market affected by the decline in capital market performance (Alam et al., 2017; Razak, Saiti, \& Dinç, 2019). This decline in performance will undoubtedly result in disruptions in both cash flow and repayment of financing to banks so that banks will slightly reduce their distribution of financing.

The shock of the composite stock index seemed to be responded to by Islamic banking financing. The stock market development can positively or negatively affect bank financing (Aluko \& Ajayi, 2018). The developing stock market condition positively impacts bank financing (Benczúr, Karagiannis, \& Kvedaras, 2019). However, if the stock market and the banking market are two sides that replace each other, then the impact of the stock market development on banks is negative (Alam et al., 2017). 


\section{Forecast Error Variance Decomposition}

In the long term, the economic variables influence, although not as significant as the financing innovation's influence. The innovation of the interest rate variable (RATE) is the most significant compared to other economic variables and the observation with an average of 3.56 percent. Furthermore, the Islamic stock index (JII) variable was 0.98 percent, the inflation rate was 0.422 percent, the rupiah exchange rate was 0.25 percent, and the composite stock index (IHSG) was 0.24 percent.

Improved performance on the capital market is a reflection of improving general economic conditions. The increase in financing contributes to driving the real sector's performance, although the effect is not too significant (Naqvi et al., 2018). Besides, Islamic banking financing that funds the real sector does not receive shocks originating from the capital market.

Changes in exchange rates contribute to explaining the diversity of financing and a factor affecting financing performance. This condition is inseparable from exchange rate fluctuations because the Murabaha scheme more dominates the Islamic banking financing composition (Aysan et al., 2018; Siswantoro, 2014). However, the proportion arising from these variables is tiny. The diversity of exchange rates is vital for every economic entity, especially entrepreneurs who carry out export-import transactions.

\section{Conclusion}

Based on the results and discussion above, this study concludes that only interest rates affect Islamic banking financing in the agricultural sector in the short term. Customers still rely on interest rates compared to the profit-sharing rates between the customer and the bank. Meanwhile, in the long term, only the inflation variable affects the financing of the agricultural sector. This condition illustrates that an increase in inflation will undoubtedly accompany financing. Moreover, the impulse response function test results show that Islamic banking financing in the agricultural sector reaches the fastest stability when it responds to shocks from the exchange rate, followed by interest rates, inflation, Islamic stock index, and composite stock index. The forecast error variance decomposition test results show that the agricultural sector's financing dominates the diversity of financing the agricultural sector itself, then interest rates, Islamic stock index, inflation, exchange rates, and the composite stock index.

The results of this study become a consideration for Islamic banking in channeling financing to the agricultural sector. The government needs to issue policies to stabilize economic turmoil to accelerate Islamic banking financing to the agricultural sector. Apart from these compelling results, this study only focuses on financing the agricultural sector so that further research can analyze it in other sectors. In addition, further research can consider other economic variables, such as the crisis, Islamic bonds, gross domestic product, and industrial production index. 


\section{Author's Declaration}

The author made substantial contributions to the conception and design of the study. The author took responsibility for data analysis, interpretation and discussion of results. The author read and approved the final manuscript.

\section{ORCID}

Faizul Mubarok (D) https://orcid.org/0000-0003-4123-6696

\section{References}

Alam, M. M., Akbar, C. S., Shahriar, S. M., \& Elahi, M. M. (2017). The Islamic Shariah principles for Investment in Stock Market. Qualitative Research in Financial Markets, 9(2), 132-146. https://doi.org/10.1108/QRFM-09-2016-0029

Aluko, O., \& Ajayi, M. A. (2018). Determinants of Banking Sector Development: Evidence from Sub-Saharan African countries. Borsa Istanbul Review, 18(2), 122139. https://doi.org/10.1016/j.bir.2017.11.002

Antle, J. M., Basso, B., Conant, R. T., Godfray, H. C. J., Jones, J. W., Herrero, M., Wheeler, T. R. (2017). Towards a New Generation of Agricultural System Data, Models and Knowledge Products: Design and Improvement. Agricultural Systems, 155, 255-268. https://doi.org/10.1016/j.agsy.2016.10.002

Apergis, N., Cooray, A., Khraief, N., \& Apergis, I. (2019). Do Gold Prices Respond to Real Interest Rates? Evidence from the Bayesian Markov Switching VECM model. Journal of International Financial Markets, Institutions and Money, 60, 134148. https://doi.org/10.1016/j.intfin.2018.12.014

Arun, T., \& Kamath, R. (2015). Financial Inclusion: Policies and Practices. IIMB Management Review, 27(4), 267-287. https://doi.org/10.1016/j.iimb.2015.09.004

Ayedh, A. M. A., Shaharuddin, A., \& Kamaruddin, M. I. H. (2019). Shariah Screening Methodology: Does It 'Really' Shariah Compliance? Iqtishadia, 12(2), 144. https://doi.org/10.21043/iqtishadia.v12i2.5573

Aysan, Ahmet F., Disli, M., \& Ozturk, H. (2018). Bank Lending Channel in a Dual Banking System: Why are Islamic Banks so Responsive? World Economy, 41(3), 674-698. https://doi.org/10.1111/twec.12507

Aysan, Ahmet Faruk, \& Disli, M. (2019). Small Business Lending and Credit Risk: Granger Causality Evidence. Economic Modelling, 83, 245-255.

https://doi.org/10.1016/j.econmod.2019.02.014

Bahloul, S., Mroua, M., \& Naifar, N. (2017). The Impact of Macroeconomic and Conventional Stock Market Variables on Islamic Index Returns under Regime Switching. Borsa Istanbul Review, 17(1), 62-74.

https://doi.org/10.1016/j.bir.2016.09.003

Benczúr, P., Karagiannis, S., \& Kvedaras, V. (2019). Finance and Economic Growth:

Financing Structure and Non-Linear Impact. Journal of Macroeconomics, 62, 1-49. https://doi.org/10.1016/j.jmacro.2018.08.001

Bitar, M., Pukthuanthong, K., \& Walker, T. (2019). Efficiency in Islamic vs. 
Conventional Banking: The Role of Capital and Liquidity. Global Finance Journal, 46, 1-40. https://doi.org/10.1016/j.gfj.2019.100487

Caporale, G. M., Çatık, A. N., Helmi, M. H., Menla Ali, F., \& Tajik, M. (2020). The Bank Lending Channel in the Malaysian Islamic and Conventional Banking System. Global Finance Journal, 45, 1-26. https://doi.org/10.1016/j.gfj.2019.100478

Chadwick, M. G. (2018). Effectiveness of monetary and macroprudential shocks on consumer credit growth and volatility in Turkey. Central Bank Review, 18(2), 6983. https://doi.org/10.1016/j.cbrev.2018.03.001

Chockalingam, A., Dabadghao, S., \& Soetekouw, R. (2018). Strategic Risk, Banks, and Basel III: Estimating Economic Capital Requirements. Journal of Risk Finance, 19(3), 225-246. https://doi.org/10.1108/JRF-11-2016-0142

Christiaensen, L. (2017). Agriculture in Africa - Telling myths from facts: A synthesis. Food Policy, 67, 1-11. https://doi.org/10.1016/j.foodpol.2017.02.002

Cieslak, A., \& Schrimpf, A. (2019). Non-monetary News in Central Bank Communication. Journal of International Economics, 118, 293-315. https://doi.org/10.1016/j.jinteco.2019.01.012

Coibion, O., Gorodnichenko, Y., Kumar, S., \& Pedemonte, M. (2020). Inflation Expectations as a Policy Tool? Journal of International Economics, 124, 1-27. https://doi.org/10.1016/j.jinteco.2020.103297

El Alaoui, A. O., Jusoh, H. Bin, Yussof, S. A., \& Hanifa, M. H. (2019). Evaluation of Monetary Policy: Evidence of the Role of Money from Malaysia. Quarterly Review of Economics and Finance, 74, 119-128. https://doi.org/10.1016/j.qref.2019.04.005

Ellington, M. (2018). Financial Market Illiquidity Shocks and Macroeconomic Dynamics: Evidence from the UK. Journal of Banking and Finance, 89, 225-236. https://doi.org/10.1016/j.jbankfin.2018.02.013

Fecke, W., Feil, J., \& Musshoff, O. (2016). Determinants of Loan Demand in Agriculture: Empirical Evidence from Germany. Agricultural Finance Review, 76(4), 462-476. https://doi.org/10.1108/AFR-05-2016-0042

Fielke, S., Taylor, B., \& Jakku, E. (2020). Digitalisation of Agricultural Knowledge and Advice Networks: A state-of-the-art review. Agricultural Systems, 180, 1-11. https://doi.org/10.1016/j.agsy.2019.102763

Galadima, M. D., \& Aminu, A. W. (2019). Shocks Effects of Macroeconomic Variables on Natural Gas Consumption in Nigeria: Structural VAR with sign restrictions. Energy Policy, 125, 135-144. https://doi.org/10.1016/j.enpol.2018.10.021

Gardner, T. A., Benzie, M., Börner, J., Dawkins, E., Fick, S., Garrett, R., Godar, J., Grimard, A., Lake, S., Larsen, R. K., Mardas, N., McDermott, C. L., Meyfroidt, P., Osbeck, M., Persson, M., Sembres, T., Suavet, C., Strassburg, B., Trevisan, A., ... Wolvekamp, P. (2019). Transparency and Sustainability in Global Commodity Supply Chains. World Development, 121, 163-177. https://doi.org/10.1016/j.worlddev.2018.05.025

Gatfaoui, H. (2017). Equity Market Information and Credit Risk Signaling: A Quantile Cointegrating Regression Approach. Economic Modelling, 64, 48-59. https://doi.org/10.1016/j.econmod.2017.03.012 
Godil, D. I., Sarwat, S., Sharif, A., \& Jermsittiparsert, K. (2020). How Oil Prices, Gold Prices, Uncertainty and Risk Impact Islamic and Conventional Stocks? Empirical Evidence from QARDL Technique. Resources Policy, 66, 1-9. https://doi.org/10.1016/j.resourpol.2020.101638

Graeub, B. E., Chappell, M. J., Wittman, H., Ledermann, S., Kerr, R. B., \& GemmillHerren, B. (2016). The State of Family Farms in the World. World Development, 87, 1-15. https://doi.org/10.1016/j.worlddev.2015.05.012

Hamza, H., \& Saadaoui, Z. (2018). Monetary Transmission Through the Debt Financing Channel of Islamic Banks: Does PSIA Play a Role? Research in International Business and Finance, 45(3), 557-570. https://doi.org/10.1016/j.ribaf.2017.09.004

Hossain, A. A. (2016). Inflationary Shocks and Real Output Growth in Nine Muslimmajority Countries: Implications for Islamic Banking and Finance. Journal of Asian Economics, 45, 56-73. https://doi.org/10.1016/j.asieco.2016.06.004

Hossain, I., Muhammad, A. D., Jibril, B. T., \& Kaitibie, S. (2019). Support for smallholder farmers through Islamic instruments: The case of Bangladesh and lessons for Nigeria. International Journal of Islamic and Middle Eastern Finance and Management, 12(2), 154-168. https://doi.org/10.1108/IMEFM-11-2018-0371

Kabir, M. N., Worthington, A., \& Gupta, R. (2015). Comparative Credit Risk in Islamic and Conventional bank. Pacific Basin Finance Journal, 34, 327-353. https://doi.org/10.1016/j.pacfin.2015.06.001

Kandil, M. (2014). On the Effects of Monetary Policy Shocks in Developing Countries. Borsa Istanbul Review, 14(2), 104-118. https://doi.org/10.1016/j.bir.2014.04.001

Kavya, T. B., \& Shijin, S. (2020). Economic Development, Financial Development, and Income Inequality Nexus. Borsa Istanbul Review, 20(1), 80-93. https://doi.org/10.1016/j.bir.2019.12.002

Khmel, V., \& Zhao, S. (2016). Arrangement of Financing for Highway Infrastructure Projects under the Conditions of Public-Private Partnership. IATSS Research, 39(2), 138-145. https://doi.org/10.1016/j.iatssr.2015.05.002

Krishna, V. V., Kubitza, C., Pascual, U., \& Qaim, M. (2017). Land markets, Property rights, and Deforestation: Insights from Indonesia. World Development, 99, 335349. https://doi.org/10.1016/j.worlddev.2017.05.018

Kudrin, A., \& Gurvich, E. (2015). A New Growth Model for the Russian Economy. Russian Journal of Economics, 1(1), 30-54. https://doi.org/10.1016/j.ruje.2015.05.002

Lawal, A. I., Somoye, R. O., Babajide, A. A., \& Nwanji, T. I. (2018). The Effect of Fiscal and Monetary Policies Interaction on Stock Market Performance: Evidence from Nigeria. Future Business Journal, 4(1), 16-33.

Lin, S., Shi, K., \& Ye, H. (2018). Exchange Rate Volatility and Trade: The Role of Credit Constraints. Review of Economic Dynamics, 30, 203-222. https://doi.org/10.1016/j.red.2018.05.002

Louhichi, A., \& Boujelbene, Y. (2016). Credit Risk, Managerial Behaviour and Macroeconomic Equilibrium within Dual Banking Systems: Interest-free vs. Interest-based Banking Industries. Research in International Business and Finance, 38, 104-121. https://doi.org/10.1016/j.ribaf.2016.03.014 
Mahapatra, S., \& Bhaduri, S. (2019). Dynamics of the Impact of Currency Fluctuations on Stock Markets in India: Assessing the Pricing of Exchange Rate Risks. Borsa Istanbul Review, 19(1), 15-23. https://doi.org/10.1016/j.bir.2018.04.004

Mueller, B., \& Mueller, C. (2016). The Political Economy of the Brazilian Model of Agricultural Development: Institutions versus Sectoral Policy. Quarterly Review of Economics and Finance, 62, 12-20. https://doi.org/10.1016/j.qref.2016.07.012

Nahar, S., \& Sarker, N. (2016). Are Macroeconomic Factors Substantially Influential For Islamic Bank Financing? Cross-Country Evidence. IOSR Journal of Business and Management, 18(6), 2319-7668. https://doi.org/10.9790/487X-1806012027

Naifar, N. (2016). Do Global Risk Factors and Macroeconomic Conditions Affect Global Islamic Index Dynamics? A Quantile Regression Approach. Quarterly Review of Economics and Finance, 61, 29-39. https://doi.org/10.1016/j.qref.2015.10.004

Naqvi, B., Rizvi, S. K. A., Uqaili, H. A., \& Chaudhry, S. M. (2018). What Enables Islamic Banks to Contribute in Global Financial Reintermediation? Pacific Basin Finance Journal, 52, 5-25. https://doi.org/10.1016/j.pacfin.2017.12.001

Nayak, A., Pai, M., \& Pai, R. (2016). Prediction Models for Indian Stock Market. Procedia Computer Science, 89, 441-449. https://doi.org/10.1016/j.procs.2016.06.096

Nolte, K., \& Ostermeier, M. (2017). Labour Market Effects of Large-Scale Agricultural Investment: Conceptual Considerations and Estimated Employment Effects. World Development, 98, 430-446. https://doi.org/10.1016/j.worlddev.2017.05.012

Nwakoby, C., \& Bernard, A. U. (2016). Effect of Health Investment on Economic Growth in Nigeria. Journal of Social Development, 5(4), 150-167. https://doi.org/10.9790/5933-0123947

Ozili, P. K. (2018). Impact of Digital Finance on Financial Inclusion and Stability. Borsa Istanbul Review, 18(4), 329-340. https://doi.org/10.1016/j.bir.2017.12.003

Rashid, A., Hassan, M. K., \& Shah, M. A. R. (2020). On The Role of Islamic and Conventional Banks in the Monetary Policy Transmission in Malaysia: Do Size and Liquidity Matter? Research in International Business and Finance, 52, 1-33. https://doi.org/10.1016/j.ribaf.2019.101123

Razak, S. S., Saiti, B., \& Dinç, Y. (2019). The Contracts, Structures and Pricing Mechanisms of Sukuk: A Critical Assessment. Borsa Istanbul Review, 19(1), 21-33. https://doi.org/10.1016/j.bir.2018.10.001

Rizvi, S. A. R., Narayan, P. K., Sakti, A., \& Syarifuddin, F. (2019). Role of Islamic Banks in Indonesian Banking Industry: an Empirical Exploration. Pacific Basin Finance Journal, (February), 1-10. https://doi.org/10.1016/j.pacfin.2019.02.002 Rothenberg, A., Gaduh, A., Burger, N., Chazali, C., Tjandraningsih, I., Radikun, R., Sutera, C., \& Weilant, S. (2016). Rethinking Indonesia's Informal Sector. World Development, 80, 96-113. https://doi.org/10.1016/j.worlddev.2015.11.005

Salman, A., \& Nawaz, H. (2018). Islamic Financial System and Conventional Banking: A Comparison. Arab Economic and Business Journal, 13(2), 155-167. https://doi.org/10.1016/j.aebj.2018.09.003

Šeho, M., Bacha, O. I., \& Smolo, E. (2020). The Effects of Interest Rate on Islamic Bank Financing Instruments: Cross-country Evidence from Dual-banking Systems. 
Pacific-Basin Finance Journal, 63, 1-27.

https://doi.org/10.1016/J.PACFIN.2020.101292

Shankland, A., \& Gonçalves, E. (2016). Imagining Agricultural Development in SouthSouth Cooperation: The Contestation and Transformation of ProSAVANA.

World Development, 81, 35-46. https://doi.org/10.1016/j.worlddev.2016.01.002

Siami-Namini, S., \& Hudson, D. (2019). The Impacts of Sector Growth and Monetary

Policy on Income Inequality in Developing Countries. Journal of Economic Studies, 46(3), 591-610. https://doi.org/10.1108/JES-08-2017-0243

Sinyakov, A., \& Yudaeva, K. (2016). Central Bank Policy Under Significant Balance-ofpayment Shocks and Structural Shifts. Russian Journal of Economics, 2(3), 246-278. https://doi.org/10.1016/j.ruje.2016.09.001

Siswantoro, D. (2014). Analysis of Islamic Bank's Performance and Strategy After Spin-off as Islamic Full-fledged Scheme in Indonesia. Procedia - Social and Behavioral Sciences, 164, 41-48. https://doi.org/10.1016/j.sbspro.2014.11.048

Sofhian. (2015). The Rationality Prohibition of Riba (Usury). Al-Ulum, 15(1), 237-266.

Speirs, J., McGlade, C., \& Slade, R. (2015). Uncertainty in the Availability of Natural

Resources: Fossil Fuels, Critical Metals and Biomass. Energy Policy, 87, 654-664. https://doi.org/10.1016/j.enpol.2015.02.031

Sugiharti, L., Esquivias, M. A., \& Setyorani, B. (2020). The Impact of Exchange rate Volatility on Indonesia's Top Exports to the Five Main Export Markets. Heliyon, 6(1), 1-14. https://doi.org/10.1016/j.heliyon.2019.e03141

Wahyudi, I., \& Sani, G. A. (2014). Interdependence Between Islamic Capital Market and Money Market: Evidence from Indonesia. Borsa Istanbul Review, 14(1), 32-47. https://doi.org/10.1016/j.bir.2013.11.001

Werner, R. (2016). A Lost Century in Economics: Three Theories of Banking and the Conclusive Evidence. International Review of Financial Analysis, 46, 361-379. https://doi.org/10.1016/j.irfa.2015.08.014

Wolfert, S., Ge, L., Verdouw, C., \& Bogaardt, M. J. (2017). Big Data in Smart Farming A review. Agricultural Systems, 153, 69-80. https://doi.org/10.1016/j.agsy.2017.01.023

Wu, L., \& Zeng, H. (2019). The Impact of Liquidity Constraints on the Cash-futures Basis Dynamics: Evidence from the Chinese Market. Economic Modelling, 83, 96110. https://doi.org/10.1016/j.econmod.2019.02.001

Yin, L., \& Ma, X. (2018). Causality Between Oil Shocks and Exchange Rate: A Bayesian, graph-based VAR Approach. Physica A: Statistical Mechanics and Its Applications, 508, 434-453. https://doi.org/10.1016/j.physa.2018.05.064 